\title{
Association of Hypertension and Chronic Kidney Disease in Population Aged $\geq 18$ Years Old
}

\author{
Rizka Ramadhanti ${ }^{1}$, Helda $^{2}$ \\ ${ }^{1}$ Public Health Study Program, Faculty of Public Health, Universitas Indonesia, Depok, Indonesia \\ ${ }^{2}$ Epidemiology Department, Faculty of Public Health, Universitas Indonesia, Depok, Indonesia
}

Background: Chronic kidney disease (CKD) is a global public health problem, due to the increasing prevalence and incidence of kidney failure, poor prognosis, and required high costs for its treatment. Hypertension as the dominant risk factor for CKD also has a high prevalence which keep increasing in DKI Jakarta. This study aimed to determine the association between hypertension and the incidence of CKD in people aged $\geq 18$ years old in DKI Jakarta Province.

Materials and method: This was a quantitative research with an analytic cross-sectional study design. The data source used was secondary data obtained from Basic Health Research (Riset Kesehatan Dasar/Riskesdas) 2018. There were 7,141 samples that matched the inclusion and exclusion criteria.

Results: The proportion of CKD and hypertension in people aged $\geq 18$ years old in DKI Jakarta Province were $0.5 \%$ and $16.6 \%$, respectively. There was a significant association between hypertension and CKD with a prevalence odds ratio (POR) of 3.140 (95\% Cl: 1.527-6.453) after being adjusted by the age variable. Several other characteristics such as age (POR $=3.912 ; 95 \%$ $\mathrm{Cl}: 1.932-7.918)$, diabetes mellitus ( $\mathrm{POR}=3.412 ; 95 \% \mathrm{Cl}: 1.405-8.285)$, heart disease ( $\mathrm{POR}=7.323 ; 95 \% \mathrm{Cl}: 3.158-16.982)$, and physical activity ( $P O R=2.324 ; 95 \% \mathrm{Cl}: 1.148-4.703$ ) were also significantly associated with the incidence of CKD.

Conclusion: Someone who has hypertension has 3.14 times (95\% Cl: 1.527-6.453; $p$-value $=0.002$ ) chance of suffering from CKD compared to someone who does not have hypertension after being controlled by the confounding variable, age.

Keywords: chronic kidney disease, hypertension, DKI Jakarta, Basic Health Research 2018

\section{Introduction}

Chronic kidney disease (CKD) is a global public health problem, due to the increasing prevalence and incidence of kidney failure, poor prognosis which results in more than 1 million people in the world each year dying from untreated kidney failure, and required high costs for its treatment (in Indonesia, there were 2.68 trillion rupiah of health care costs by BPJS spent on kidney disease in 2015, and it is the second largest BPJS financing). Currently more than 2 million people worldwide are undergoing treatment for CKD by doing dialysis or kidney transplantation to stay alive. ${ }^{1,2}$ Based on data obtained from the Indonesian Renal Registry in 2018, the number of new patients and active patients undergoing chronic haemodialysis in 2016-2018 has increased. ${ }^{3}$

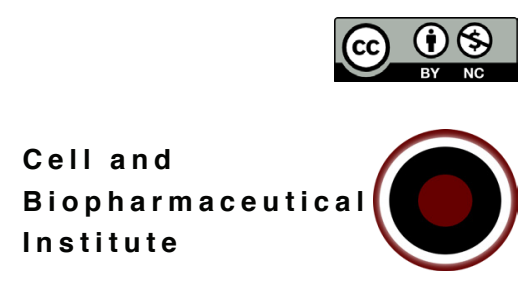


According to Basic Health Research (Riset Kesehatan Dasar/Riskesdas) 2018, the prevalence of CKD has increased when compared to Riskesdas 2013. In 2013, the prevalence of CKD in Indonesia based on a doctor's diagnosis in the population aged 15 years was $0.2 \%$, and increased to $0.38 \%$ in $2018 .{ }^{4,5}$

Hypertension is one of the dominant or major risk factors for the incidence of CKD. Previous research also found that there was a significant association between hypertension and the incidence of CKD, where someone with hypertension had 4.1 times greater risk of developing CKD compared to those without hypertension $(\mathrm{OR}=4.10$; 95\% CI: 2.94-5.72). ${ }^{6}$ Hypertension is a public health threat because it is at risk of causing various complications such as stroke, coronary heart disease, and kidney failure. ${ }^{7}$ In Indonesia, the prevalence of hypertension based on a doctor's diagnosis in the population aged 18 years in the Riskesdas 2007 is $7.2 \%{ }^{8}$ This number increased in 2013 to $9.4 \%$, then slightly decreased in 2018 to $8.36 \%{ }^{4,5}$ However, the prevalence of hypertension in DKI Jakarta Province is increasing from $9.5 \%$ in 2007 , to $10 \%$ in 2013 , and to $10.17 \%$ in $2018 ., 5,8$

In addition to hypertension, there are also several other factors that influence the incidence of CKD, such as older age, male gender, someone with diabetes mellitus (DM), heart disease, obesity, someone who has a smoking habit, consumption of alcohol, consumption of energy drinks, consumption of carbonated drinks, and someone who is less physically active.

DKI Jakarta Province is a province that experienced an increase in the prevalence of CKD in the population aged 15 years in Riskesdas 2018 (0.45\%) when compared to 2013 $(0.1 \%))^{4,5}$ The increase in the prevalence of CKD is also in line with the increase in the prevalence of hypertension. The increase in prevalence and the poor impact and prognosis of CKD has also aroused the interest of researchers to find out whether there is a association with an increase in the prevalence of hypertension in DKI Jakarta Province. Therefore, this study aims to determine the association between hypertension and the incidence of CKD in the population aged $\geq 18$ years in DKI Jakarta Province.

\section{Materials and methods}

\section{Study Design}

This was a quantitative research with an analytic crosssectional study design. The population in this study were all residents aged 18 years in DKI Jakarta Province who were respondents in the Riskesdas 2018. This study was approved by The Research and Community Engagement Ethical Committee, Faculty of Public Health, Universitas Indonesia (No. 460/UN2.F10.D11/PPM.00.02/2021).

\section{Sampling Criteria}

The sample in this study was taken using the Total Sampling method, where all Riskesdas 2018 respondents aged 18 years in DKI Jakarta Province who met the inclusion and exclusion criteria were the samples in the study. The criteria for the research sample are respondents aged 18 years who live in DKI Jakarta Province and are not pregnant, by excluding respondents with incomplete variable data in Riskesdas 2018. So that there are 7,141 respondents who fit the criteria for this research sample.

\section{Data Collection}

The data source used in this study is secondary data obtained from the results of the Riskesdas 2018 through the Data Management Laboratory, Health Research and Development Agency, Ministry of Health of the Republic of Indonesia, which can be accessed with certain requirements and procedures through www.litbang.kemkes.go.id. The secondary data used in this study were the incidence of $\mathrm{CKD}$, hypertension, age, gender, DM, heart disease, obesity, smoking habits, alcohol consumption, energy drinks, soft drinks, and physical activity.

In this study, the variables of CKD, hypertension, $\mathrm{DM}$, and heart disease were stated based on the doctor's diagnosis. Obesity status (BMI $\geq 27$ ) was obtained based on the results of the calculation of the respondent's weight and height at the time of the survey. The status of smoking habits was obtained based on the history of cigarette consumption during the respondent's life until the interview was conducted. The status of consumption of alcohol, energy drinks, and carbonated drinks was obtained based on the frequency of consumption in the last month until the interview was conducted. While the status of physical activity was obtained based on the average time and frequency of physical activity carried out in one week.

\section{Statistical Analysis}

The analysis in this study includes univariate, bivariate, and multivariate analysis. Bivariate analysis was performed using the chi square test for categorical data, using a $95 \%$ Confidence Interval (CI). In addition, the measure of 
association used to determine the association between the dependent and independent variables in this study is the Prevalence Odds Ratio (POR). While the type of multivariate analysis used in this study is multiple logistic regression with a risk factor model. Analysis will be performed using IBM SPSS (Statistical Package for the Social Sciences) Statistics 22 (IBM Corporation, New York, Armonk, USA).

\section{Results}

Based on Table 1, it was found that only a small proportion of respondents $(0.5 \%)$ had $\mathrm{CKD}$, while there were $16.6 \%$ of respondents who had hypertension. Based on the characteristics, $32.1 \%$ of respondents were aged $>50$ years, $42.7 \%$ were male, $6 \%$ had DM, 3.5\% had heart disease, $34 \%$ were obese, $39 \%$ have a smoking habit, $2.8 \%$ have a habit of consuming alcohol, $2.3 \%$ consume energy drinks 3 times per week, $3.3 \%$ consume carbonated drinks 3 times per week, and $44.2 \%$ have lacked of physical activity.

Based on the results of the bivariate analysis which can be seen in Table 2, the factors associated with the incidence of CKD include having hypertension $(\mathrm{POR}=4.529 ; 95 \% \mathrm{CI}$ : $2.303-8.907)$, aged $>50$ years $(\mathrm{POR}=3.912 ; 95 \%$ CI: 1.932 7.918), had DM (POR=3.412; 95\% CI: 1.405-8.285), had heart disease ( $\mathrm{POR}=7.323 ; 95 \% \mathrm{CI}: 3.158-16.986)$, and lacked of physical activity $(\mathrm{POR}=2.324 ; 95 \% \mathrm{CI}$ : 1.148 4.703).

Multivariate analysis begins with conducting a full model. The analysis was carried out on all variables including the main variable, all candidate confounding variables, and candidate interaction variables. Interaction is made between the main independent variable and all candidate confounding variables. ${ }^{9}$ After the analysis, the full modeling results are obtained in Table 3.

After obtaining the full model results, an interaction assessment was carried out by conducting a homogeneity test based on the $p$-value. If the variable has a $p$-value $<0.05$, then there is an interaction. After the interaction assessment was carried out, it turned out that there were no interaction variables, so the analysis continued to the confounding assessment stage.

The confounding assessment is carried out by removing the candidate confounding variables from the model one by one in sequence from the one with the largest $p$-value. If the change in the POR value of the main independent variable is $>10 \%$ when the confounding candidate variable is removed, then the variable is a confounding variable, so it must be
Table 1. Subject characteristics.

\begin{tabular}{|c|c|c|}
\hline Characteristics & $\begin{array}{c}\text { Frequency } \\
\text { (n) }\end{array}$ & $\begin{array}{c}\text { Percentage } \\
\text { (\%) }\end{array}$ \\
\hline \multicolumn{3}{|l|}{$\overline{\mathrm{CKD}}$} \\
\hline Yes & 34 & 0.5 \\
\hline No & 7,107 & 99.5 \\
\hline \multicolumn{3}{|l|}{ Hypertension } \\
\hline Yes & 1,182 & 16.6 \\
\hline No & 5,959 & 83.4 \\
\hline \multicolumn{3}{|l|}{$\overline{\text { Age }}$} \\
\hline$>50$ years old & 2,290 & 32.1 \\
\hline $18-50$ years old & 4,851 & 67.9 \\
\hline \multicolumn{3}{|l|}{$\overline{\text { Sex }}$} \\
\hline Male & 3,051 & 42.7 \\
\hline Female & 4,090 & 57.3 \\
\hline \multicolumn{3}{|l|}{ Diabetes mellitus } \\
\hline Yes & 426 & 6 \\
\hline No & 6,715 & 94 \\
\hline \multicolumn{3}{|l|}{ Heart disease } \\
\hline Yes & 250 & 3.5 \\
\hline No & 6,891 & 96.5 \\
\hline \multicolumn{3}{|l|}{ Obesity } \\
\hline Yes & 2,426 & 34 \\
\hline No & 4,715 & 66 \\
\hline \multicolumn{3}{|l|}{ Smoking habit } \\
\hline Yes & 2,785 & 39 \\
\hline No & 4,356 & 61 \\
\hline \multicolumn{3}{|l|}{ Alcohol consumption } \\
\hline Yes & 201 & 2.8 \\
\hline No & 6,940 & 97.2 \\
\hline \multicolumn{3}{|l|}{ Energy drink consumption } \\
\hline$\geq 3$ times per week & 162 & 2.3 \\
\hline$<3$ times per week & 6,979 & 97.7 \\
\hline \multicolumn{3}{|c|}{ Carbonated drink consumption } \\
\hline$\geq 3$ times per week & 237 & 3.3 \\
\hline$<3$ times per week & 6,904 & 96.7 \\
\hline \multicolumn{3}{|l|}{ Physical activity } \\
\hline Less & 3,156 & 44.2 \\
\hline Adequate & 3,985 & 55.8 \\
\hline
\end{tabular}

re-entered and remains in the model. ${ }^{9}$ After conducting the confounding assessment, the results are shown in Table 4.

Based on the results of the analysis, it was found that the main independent variable, hypertension, had a change in the POR value $>10 \%$ after the age variable was removed from the model. Thus, the age variable must be re-entered into the model and is a confounding variable. 
Table 2. Association of hypertension and others subject characteristics related to CKD.

\begin{tabular}{|c|c|c|c|c|}
\hline \multirow{2}{*}{ Characteristics } & \multicolumn{2}{|c|}{ CKD } & \multirow{2}{*}{ POR (95\% CI) } & \multirow{2}{*}{$p$-value } \\
\hline & Yes & No & & \\
\hline \multicolumn{5}{|l|}{ Hypertension } \\
\hline Yes & $16(47.1 \%)$ & $1,166(16.4 \%)$ & $4.529(2.303-8.907)$ & 0 \\
\hline No & $18(52.9 \%$ & $5,941(83.6 \%)$ & 1 & \\
\hline \multicolumn{5}{|l|}{ Age } \\
\hline$>50$ years old & $22(64.7 \%)$ & $2,268(31.9 \%)$ & $3.912(1.932-7.918)$ & 0 \\
\hline $18-50$ years old & $12(35.3 \%)$ & $4,839(68.1 \%)$ & 1 & \\
\hline \multicolumn{5}{|l|}{ Sex } \\
\hline Male & $19(55.9 \%)$ & $3,032(42.7 \%)$ & $1.702(0.864-3.356)$ & 0.167 \\
\hline Female & $15(44.1 \%)$ & $4,075(57.3 \%)$ & 1 & \\
\hline \multicolumn{5}{|l|}{ Diabetes mellitus } \\
\hline Yes & $6(17.6 \%)$ & $420(5.9 \%)$ & $3.412(1.405-8.285)$ & 0.014 \\
\hline No & $28(82.4 \%)$ & $6,687(94.1 \%)$ & 1 & \\
\hline \multicolumn{5}{|l|}{ Heart disease } \\
\hline Yes & $7(20.6 \%)$ & $243(3.4 \%)$ & $7.323(3.158-16.986)$ & 0 \\
\hline No & $27(79.4 \%)$ & $6,864(96.6 \%)$ & 1 & \\
\hline \multicolumn{5}{|l|}{$\overline{\text { Obesity }}$} \\
\hline Yes & $9(26.5 \%)$ & $2,417(34 \%)$ & $0.699(0.326-1.499)$ & 0.457 \\
\hline No & $25(73.5 \%)$ & $4,690(66 \%)$ & 1 & \\
\hline \multicolumn{5}{|l|}{ Smoking habit } \\
\hline Yes & $15(44.1 \%)$ & $2,770(39 \%)$ & $1.236(0.627-2.437)$ & 0.662 \\
\hline No & $19(55.9 \%)$ & $4,337(61 \%)$ & 1 & \\
\hline \multicolumn{5}{|l|}{ Alcohol consumption } \\
\hline Yes & $0(0.00 \%)$ & $201(2.8 \%)$ & . & 1 \\
\hline No & $34(100 \%)$ & $6,906(97.2 \%)$ & 1 & \\
\hline \multicolumn{5}{|l|}{ Energy drink consumption } \\
\hline$\geq 3$ times per week & $1(2.9 \%)$ & $161(2.3 \%)$ & $1.307(0.178-9.617)$ & 0.543 \\
\hline$<3$ times per week & $33(97.1 \%)$ & $6,946(97.7 \%)$ & 1 & \\
\hline \multicolumn{5}{|c|}{ Carbonated drink consumption } \\
\hline$\geq 3$ times per week & $1(2.9 \%)$ & $236(3.3 \%)$ & $0.882(0.120-6.478)$ & 1 \\
\hline$<3$ times per week & $33(97.1 \%)$ & $6,871(96.7 \%)$ & 1 & \\
\hline \multicolumn{5}{|l|}{ Physical activity } \\
\hline Less & $22(64.7 \%)$ & $3,134(44.1 \%)$ & $2.324(1.148-4.703)$ & 0.025 \\
\hline Adequate & $12(35.3 \%)$ & $3,973(55.9 \%)$ & 1 & \\
\hline
\end{tabular}

Final model of the association between hypertension and the incidence of CKD based on the results of multivariate analysis can be seen in Table 5, where someone with hypertension has 3.14 times chance $(\mathrm{POR}=3.140$; 95\% CI: 1.527-6.453) to suffer from CKD when compared with someone who does not have hypertension after being controlled by the confounding variable, namely age.

\section{Discussion}

Based on the results of bivariate analysis, there is a significant association between hypertension, age, DM, heart disease, and physical activity toward CKD. While there is no significant association between gender, obesity, smoking habits, alcohol consumption, energy drinks, and carbonated drinks toward CKD. 
Table 3. Full model analysis of the association between hypertension and CKD.

\begin{tabular}{lcc}
\hline \multicolumn{1}{c}{ Variable } & POR (95\% CI) & p-value \\
\hline Hypertension & $3.472(0.552-21.839)$ & 0.185 \\
Age & $2.355(0.876-6.334)$ & 0.09 \\
Sex & $0.955(0.251-3.629)$ & 0.947 \\
Diabetes Mellitus & $3.211(0.857-12.033)$ & 0.083 \\
Heart disease & $1.820(0.231-14.331)$ & 0.57 \\
Obesity & $0.678(0.219-2.092)$ & 0.499 \\
Smoking habit & $0.959(0.252-3.654)$ & 0.951 \\
Energy drink consumption & $4.626(0.578-37.016)$ & 0.149 \\
Carbonated drink consumption & $0.000(0,000-)$. & 0.995 \\
Physical activity & $2.698(0.991-7.345)$ & 0.052 \\
Hypertension*Age & $0.669(0.127-3.536)$ & 0.636 \\
Hypertension*Sex & $3.488(0.553-21.985)$ & 0.183 \\
Hypertension*Diabetes Mellitus & $0.292(0.045-1.903)$ & 0.198 \\
Hypertension*Heart disease & $2.699(0.260-27.970)$ & 0.405 \\
Hypertension*Obesity & $0.893(0.185-4.305)$ & 0.888 \\
Hypertension*Smoking habit & $0.669(0.108-4.137)$ & 0.665 \\
Hypertension*Energy drink consumption & $0.000(0.000-)$. & 0.998 \\
Hypertension*Carbonated drink consumption & $28081317.154(0.000-)$. & 0.995 \\
Hypertension*Physical activity & $0.586(0.137-2.515)$ & 0.473 \\
\hline
\end{tabular}

A person aged $>50$ years old has 3.9 times chance of suffering from CKD compared to someone aged 18-50 years old. Another study found that there was a significant association between age and the incidence of $\mathrm{CKD}$, a person aged 49-65 years had a 13.57 times chance $(\mathrm{OR}=13.57$; 95\% CI: 4.73-38.97) to suffer from CKD compared to with someone aged $25-48$ years. ${ }^{10}$ Kidney function decreases with age, in both men and women. The elderly population is more at risk for developing CKD after various kidney disorders. ${ }^{11}$ Aging or increasing age is associated with changes in activity and response to vasoactive stimuli, so that the response to vasoconstrictor stimuli is increased and the vasodilation response is impaired. These changes can then lead to acute kidney injury, including normotensive ischemic nephropathy, and progressive CKD. ${ }^{12}$

Someone who has DM has 3.4 times chance of suffering from CKD compared to someone who does not have DM. These results are in line with previous studies which found

Table 4. Confounding assessment result of the association between hypertension and CKD.

\begin{tabular}{lcc}
\hline \multicolumn{1}{c}{ Model } & $\begin{array}{c}\text { Hypertension OR } \\
(\mathbf{9 5 \%} \mathbf{C I})\end{array}$ & $\Delta$ Hypertension OR \\
\hline Full Model without Interaction Variable & $2.926(1.348-6.352)$ & $\cdot$ \\
Without Carbonated Drink Consumption Variable & $2.924(1.347-6.349)$ & $0.07 \%$ \\
Without Smoking Habit Variable & $2.944(1.358-6.383)$ & $0.62 \%$ \\
Without Energy Drink Consumption Variable & $2.943(1.358-6.377)$ & $0.58 \%$ \\
Without Diabetes Mellitus Variable & $3.041(1.410-6.560)$ & $3.93 \%$ \\
Without Obesity Variable & $2.845(1.335-6.063)$ & $2.77 \%$ \\
Without Sex Variable & $2.676(1.262-5.676)$ & $8.54 \%$ \\
Without Physical Activity Variable & $2.695(1.281-5.670)$ & $7.89 \%$ \\
Without Age Variable & $3.632(1.792-7.361)$ & $24.13 \%$ \\
Age Variables Re-entered and Without Heart Disease Variable & $3.140(1.527-6.453)$ & $7.31 \%$ \\
\hline
\end{tabular}


Table 5. Association of hypertension and CKD after being controlled with confounding variable.

\begin{tabular}{lcc}
\hline \multicolumn{1}{c}{ Variable } & $\boldsymbol{p}$-value & POR (95\% CI) \\
\hline Hypertension & 0.002 & $3.140(1.527-6.453)$ \\
Age & 0.008 & $2.768(1.306-5.867)$ \\
\hline
\end{tabular}

that there was a significant association between DM and the incidence of CKD, someone who had DM had 4.3 times chance $(\mathrm{OR}=4.34 ; 95 \% \mathrm{CI}: 2.87-6.55)$ to suffer from $\mathrm{CKD}$ compared to someone who does not have DM. ${ }^{6}$ The kidneys cannot withstand high and uncontrolled blood sugar levels for long periods of time. DM can cause oxidative stress to cells, aggravate the work of the kidneys through the work of the renin-angiotensin-aldosterone (RAA) hormonal system, which can then cause inflammation and the development of scar tissue in the kidneys. DM is one of the factors initiating $\mathrm{CKD}$, which is a factor that can directly initiate kidney damage. DM can also be a progression factor for CKD, which is a factor that can worsen and accelerate kidney damage if the DM is not controlled for a long time. ${ }^{13}$

A person who has heart disease has 7.3 times chance of suffering from CKD compared to someone who does not have heart disease. Another study showed similar results, which found that there was a significant association between cardiovascular disease and the incidence of CKD, that a person with cardiovascular disease had 2.3 times $(\mathrm{OR}=2.35$; 95\% CI: 2.07-2.67) more likely to suffer from CKD than people without cardiovascular disease. ${ }^{14}$ When a person has heart disease, the heart cannot do its job to pump blood properly. Then the heart that is too full of blood can further put pressure on the main blood vessels connected to the kidneys, which can cause blockages and reduce the supply of oxygen-rich blood to the kidneys. This in turn can lead to kidney disease. ${ }^{15}$

A person who has a habit of less physical activity has 2.3 times chance of suffering from CKD compared to someone who has a habit of sufficient physical activity. Another study also found that someone who is not physically active had 2.2 times chance ( $\mathrm{POR}=2.2 ; 95 \% \mathrm{CI}: 1.3-3.8)$ to suffer from CKD compared to someone who is physically active. ${ }^{16}$ Physical inactivity is one of the risk factors for cardiovascular disease. In addition, physical inactivity also contributes to the incidence of obesity, diabetes, and hypertension, which are risk factors for the incidence of CKD. ${ }^{17}$ Physical activity can improve cardiovascular endothelial function and increase insulin sensitivity. A similar effect on the renal vasculature will also improve kidney function. Decreased adiposity or adipocytokines is also a positive effect of physical activity that can affect kidney health. ${ }^{18}$

Based on the results of the bivariate analysis, it was also found that someone who has hypertension has 4.5 times chance of suffering from CKD compared to someone who did not have hypertension. Meanwhile, based on the results of multivariate analysis, it was found that someone who has hypertension has 3.14 times chance of suffering from CKD when compared to someone who did not have hypertension after being controlled by the confounding variable, namely age. All previous studies found also stated similar results that hypertension was a risk factor for CKD. For example, a cross-sectional study that used data from an initial study of PTM cohorts in residents aged 25-65 years in Bogor, which obtained an adjusted OR value of 3.71 (95\% CI: 1.82-7.59), which means someone who having hypertension has 3.71 times chance of suffering from CKD compared to someone who does not have hypertension. ${ }^{10}$ Research related to the prevalence and risk factors of CKD in the adult population in Thailand also found that hypertension is a risk factor for the incidence of CKD with an adjusted OR value of 1.96 (95\% CI: 1.44-2.67) which means someone who has hypertension has 1.9 times chance of suffering from CKD compared to someone who does not have hypertension. ${ }^{6}$ There were no previous studies that stated different results.

The magnitude of the effect of hypertension on the kidneys depends on the severity and duration of hypertension experienced. The higher the blood pressure and the longer you have hypertension, the more severe the complications it can cause. ${ }^{10}$ The kidneys help filter waste and extra fluid from the blood. The nephrons in the kidneys are supplied with a dense network of blood vessels and a large volume of blood flow. Over time, uncontrolled hypertension can cause the arteries around the kidneys to narrow, weaken, or harden. These damaged arteries are also unable to supply enough blood to the kidney tissue. When these blood vessels are damaged, the nephrons that filter blood are unable to receive the oxygen and nutrients they need to function properly. ${ }^{19}$ Hypertension that is not controlled continuously and for a long period of time can also result in increased intraglomerular pressure, so that it can cause the glomerulus to experience structural and functional disorders, which in turn will affect glomerular filtration and result in microalbuminuria and even proteinuria. ${ }^{20,21}$ 
The confounding variable found in this study is age, so this shows that age is a risk factor for the incidence of $\mathrm{CKD}$ and is also associated with hypertension. Based on the results of multivariate analysis, someone aged $>50$ years has 2.7 times chance of suffering from CKD compared to someone aged $\leq 50$ years. A cross-sectional study of the prevalence and risk factors for CKD in an adult population aged over 20 years in China also found that increasing age was significantly associated with the incidence of CKD with an adjusted OR value of 1.29 (95\% CI: 1.19-1.39) or every 10 year increase in age..$^{22}$

Age is a predisposing factor for the incidence of $\mathrm{CKD}^{23}$ Age is also an unavoidable risk factor for degenerative diseases, because with age all organ functions in the body including the kidneys will also decrease. ${ }^{13}$ Starting at the age of 50 years, the kidneys will experience a significant decrease in function up to about $20 \%$ due to a decrease in the number of nephrons. In addition, increasing age will also affect the anatomy and cytology of the kidneys. The kidneys will experience atrophy and a decrease in the thickness of the renal cortex..$^{24}$ The presence of degenerative diseases as the dominant risk factor for the incidence of CKD, namely hypertension and DM, also most commonly occurs in someone over 50 years old. ${ }^{25}$

In this study, there are several limitations that may affect the results of the study. First, in this cross-sectional study, it was not possible to determine a causal association, so it cannot be ascertained whether hypertension and other respondent characteristics preceded the occurrence of CKD or vice versa. Second, the variables used in this study adjust to the variables available in the Riskesdas 2018 questionnaire. Third, in this study there can be information bias because several variables such as alcohol consumption habits, energy drink consumption, carbonated drink consumption, and physical activity are obtained only by depending on the respondent's memory, thus allowing for recall bias. In addition, the interview questionnaire used was also not accompanied by the time when the subject was first diagnosed with hypertension so that it was not known how long the respondent had had hypertension.

Therefore, further study with case control or cohort study design can be conducted so the causal association between independent variables and covariates with the dependent variable can be explained. It is also necessary to add other variables that have not been studied, use data from measurements or medical or clinical examinations or laboratory for disease variables, and adding information on taking antihypertensive drugs in the operational definition of hypertension variables.

\section{Conclusion}

The prevalence of CKD and hypertension in the population aged 18 years in DKI Jakarta Province is $0.5 \%$ and $16.6 \%$, respectively. There is a significant relationship between hypertension, age, DM, heart disease, and physical activity with the incidence of CKD. Based on the results of multivariate analysis, it was found that someone with hypertension has 3.14 times (95\% CI: 1.527-6.453; $p$-value $=$ 0.002) chance of suffering from CKD compared to someone who did not have hypertension after being controlled by confounding variables.

\section{References}

1. Pusat Data dan Informasi Kementerian Kesehatan RI [Internet]. Situasi Penyakit Ginjal Kronis [updated 2017 May 4; accessed 2021 Jan 21]. Available from: https://pusdatin.kemkes.go.id/article/ view/17050400001/situasi-penyakit-ginjal-kronis.html.

2. National Kidney Foundation [Internet]. Global Facts: About Kidney Disease [accessed: 2021 Jan 21]. Available from: https://www. kidney.org/kidneydisease/global-facts-about-kidney-disease.

3. Indonesian Renal Registry [Internet]. 11th Report of Indonesian Renal Registry [updated 2018; accessed 2021 Apr 7]. Available from: https://www.indonesianrenalregistry.org/data/IRR\%202018. pdf.

4. Kementerian Kesehatan RI. Laporan Nasional Riskesdas 2013. Jakarta: Kementrian Kesehatan RI; 2013

5. Kementerian Kesehatan RI. Laporan Nasional Riskesdas 2018. Jakarta: Kementrian Kesehatan RI; 2018.

6. Ingsathit A, Thakkinstian A, Chaiprasert A, Sangthawan P, Gojaseni $\mathrm{P}$, Kiattisunthorn $\mathrm{K}$, et al. Prevalence and risk factors of chronic kidney disease in the Thai adult population: Thai SEEK study. Nephrol Dial Transplant. 2010; 25(5): 1567-75.

7. Pusat Data dan Informasi Kementerian Kesehatan RI [Internet]. Hipertensi [accessed 2021 Jan 21]. Available from: https://https:// pusdatin.kemkes.go.id/resources/download/pusdatin/infodatin/ infodatin-hipertensi.pdf.

8. Kementerian Kesehatan RI. Laporan Nasional Riskesdas 2007. Jakarta: Kementrian Kesehatan RI; 2007.

9. Hastono SP. Analisis Data. Depok: Fakultas Kesehatan Masyarakat Universitas Indonesia; 2006.

10. Sulistiowati E, Idaiani S. Faktor risiko penyakit ginjal kronik berdasarkan analisis cross-sectional data awal studi kohort penyakit tidak menular penduduk usia 25-65 tahun di Kelurahan Kebon Kalapa, Kota Bogor tahun 2011. Buletin Penelitian Kesehatan, 2015; 43(3): 163-72.

11. Kidney Disease Improving Global Outcomes. KDIGO 2012 Clinical Practice Guideline for the Evaluation and Management of Chronic Kidney Disease. Vol.3 No.1. Brussels: International Society of Nephrology; 2013.

12. Weinstein JR, Anderson S. The aging kidney: physiological changes. Adv Chronic Kidney Dis. 2010: 17(4): 302-7. 
13. Delima D, Tjitra E. Faktor risiko penyakit ginjal kronik: studi kasus kontrol di empat rumah sakit di Jakarta tahun 2014. Buletin Penelitian Kesehatan. 2017: 45(1): 17-26.

14. Sepanlou SG, Barahimi H, Najafi I, Kamangar F, Poustchi H, Shakeri $\mathrm{R}$, et al. Prevalence and determinants of chronic kidney disease in northeast of Iran: Results of the Golestan cohort study. PLOS ONE. 2017; 12(5): e0176540. doi: 10.1371/journal.pone.0176540.

15. American Kidney Fund [Internet] Heart Disease \& Chronic Kidney Disease (CKD) [accessed 2021 Jan 22]. Available from: https:// www.kidneyfund.org/kidney-disease/chronic-kidney-disease-ckd/ complications/heart-disease/\# heart-disease-ckd-connection.

16. Stengel B, Tarver-Carr ME, Powe NR, Eberhardt MS, Brancati FL. Lifestyle factors, obesity and the risk of chronic kidney disease. Epidemiology. 2003; 14(4): 479-87.

17. Robinson-Cohen C, Littman AJ, Duncan GE, Weiss NS, Sachs MC, Ruzinski J, et al. Physical activity and change in estimated GFR among persons with CKD. J Am Soc Nephrol. 2014; 25(2): 399406 .

18. Guo C, Tam T, Bo Y, Chang L, Lao XQ, Thomas, GN. Habitual physical activity, renal function and chronic kidney disease: A cohort study of nearly 200000 adults. Br J Sports Med. 2020; 54(20): 1225-30.

19. American Heart Association [Internet]. How High Blood Pressure Can Lead to Kidney Damage or Failure [updated 2016 Oct 31; accessed 2021 Feb 1]. Available from: https:/www.heart.org/en/ health-topics/high-blood-pressure/health-threats-from-high-bloodpressure/how-high-blood-pressure-can-lead-to-kidney-damage-orfailure/.

20. Pranandari R, Supadmi W. Faktor Risiko Gagal Ginjal Kronik di Unit Hemodialisis RSUD Wates Kulon Progo. 2015; 11(2): 316-320.

21. Indrayanti S, Ramadaniati H, Anggriani Y, Sarnianto P, Andayani N. Risk factors for chronic kidney disease: a case-control study in a district hospital in Indonesia. J Pharm Sci Res. 2019; 11(7): 254954.

22. Chen W, Wang H, Dong X, Liu Q, Mao H, Tan J, et al. Prevalence and risk factors associated with chronic kidney disease in an adult population from southern China. Nephrol Dial Transplant. 2008; 24(4): 1205-12.

23. Hidayati T, Kushadiwijaya H, Suhardi. Hubungan Antara Hipertensi, Merokok dan Minuman Suplemen Energi dan Kejadian Penyakit Ginjal Kronik. 2008; 24(2): 90-102.

24. Arifa SI, Azam M, Handayani OWK. Faktor yang Berhubungan dengan Kejadian Penyakit Ginjal Kronik pada Penderita Hipertensi di Indonesia. 2017; 13(4): 319-28.

25. Ariyanto, Hadisaputro S, Lestariningsih, Adi S, Budijitno S. Beberapa faktor risiko kejadian penyakit ginjal kronik (PGK) stadium V pada kelompok usia kurang dari 50 tahun. Jurnal Epidemiologi Kesehatan Komunitas. 2018; 3(1): 1-6. 